\title{
The Use of Online Learning Tools to Enhance Interaction among the Primary School Pupils with Peers and Teachers
}

Nurrul Aqilah binti Ismail, Azlina Abdul Aziz

To Link this Article: http://dx.doi.org/10.6007/IJARBSS/v11-i11/11007

DOI:10.6007/IJARBSS/v11-i11/11007

Received: 07 September 2021, Revised: 10 October 2021, Accepted: 25 October 2021

Published Online: 12 November 2021

In-Text Citation: (Ismail \& Aziz, 2021)

To Cite this Article: Ismail, N. A. binti, \& Aziz, A. A. (2021). The Use of Online Learning Tools to Enhance Interaction among the Primary School Pupils with Peers and Teachers. International Journal of Academic Research in Business and Social Sciences, 11(11), $800-817$.

Copyright: (c) 2021 The Author(s)

Published by Human Resource Management Academic Research Society (www.hrmars.com)

This article is published under the Creative Commons Attribution (CC BY 4.0) license. Anyone may reproduce, distribute, translate and create derivative works of this article (for both commercial and non-commercial purposes), subject to full attribution to the original publication and authors. The full terms of this license may be seen at: http://creativecommons.org/licences/by/4.0/legalcode

Vol. 11, No. 11, 2021, Pg. $800-817$

Full Terms \& Conditions of access and use can be found at http://hrmars.com/index.php/pages/detail/publication-ethics 


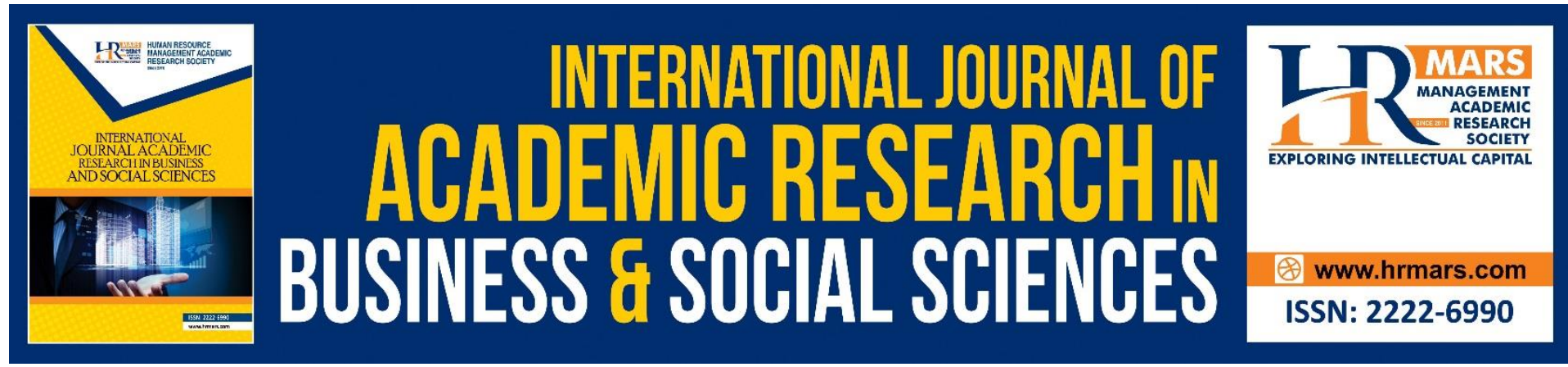

\title{
The Use of Online Learning Tools to Enhance Interaction among the Primary School Pupils with Peers and Teachers
}

\author{
Nurrul Aqilah binti Ismail, Dr. Azlina Abdul Aziz \\ The National University of Malaysia \\ Email: nurruls1993@gmail.com, azlina1@ukm.edu.my
}

\begin{abstract}
This paper is a systematic review of relevant published studies on how online learning tools can help ESL primary school pupils to enhance the interaction among their peers and teachers. This review discussed how ESL primary school pupils cope in the current situation of teaching and learning progress during the Covid-19 pandemic. The use of online teaching and learning tools has its benefits and challenges for all people involved. It also could help teachers and pupils achieve learning goals, especially during the pandemic. This paper also gives an insight on the advantages and disadvantages of different teaching and learning tools used by teachers and pupils.
\end{abstract}

Keywords: Online Teaching, Online Learning Tools, ESL, Young Learners, Interaction

\section{Introduction}

In the teaching and learning process, we had been trained that the use of correct tools could enhance students to achieve the goals in their studies. The benefits of using online platforms are not only agreeable in the education aspect only. All the sectors came to the conclusion that it is really important in everyone's life. Teachers' effort in trying to deliver the best to their pupils would be one of the ways to make sure that targeted pupils learn through the best method from the teachers. In the 21st century of teaching and learning strategies, we know that using online tools to help pupils is one of the effective ways to suit pupils' needs. Can you imagine how this world would be if there is no engagement among technology and cyber connection? We tend to use the Internet to find information and seek new knowledge in order to get updated with the current issues. The technology in the world developed well and the internet has provided a lot of opportunities for teaching and learning online (Hockly and Clandfield, 2010). Face to face learning could engage a lot of interaction among teachers and pupils. In the current situation, teachers also need to find ways to engage interaction with the pupils to instill a positive impact on their learning. (Murali Krishnamurthi) In addition, living in this century needs us to be prepared in any condition and situation. For example, nowadays we are facing a pandemic that affected the world. Education institutes are shut down and have changed from traditional learning methods where we meet each other and gather in one place to electronic learning where everything needs to be handled 
online. The needs of using online tools as a medium to deliver knowledge and information to the public or even the learners are in high demand. Teachers can monitor students in an easier way if everything is set up at the fingertips. By monitoring participation of students in online learning, teachers can give feedback on which students need to be scaffold or need more guidance. It will benefit teachers and also parents at home as well where they can monitor and guide their own children.

\section{Problem Statement}

As the country developed, there were some changes that had been implemented to increase the standard and quality of the education system in a certain country. Malaysia is one of the developing countries that is always trying its best to achieve the goals in the Curriculum Standard of Learning. Teachers are the main role in contributing to the well-being of the pupils. Teachers will learn what works best for their personalities and curriculum as they build their teaching styles and blend them with successful teaching management skills. It will help their pupils as well.

The main problem of this study is on how the pandemic enforced teaching and learning changed its way from the traditional to the conventional style. It also focussed on ways to suit the current needs of education. The demands set by the surrounding shows that it should have some improvement in teaching and learning process. Nowadays, teachers need to equip themselves with the latest and updated skills in delivering the content of the teaching. In order to produce the holistic generation, the provider needs to be well prepared before it comes in hand. The pressure from the government to have equal access to all the learners in all the categories had forced all the MPs and the policy maker to come out with their initiative to help in any possible ways. Since the pandemic has become worse in this country, the Ministry of Education (KPM) is trying to prepare the tools for both teachers and pupils in order to access the infinite world of opportunities. Some of the examples of the preparation given are the free internet data to the learners who are eligible and some of the ministers even provided the equipment such like laptops and materials needed for the pupils to access the internet.

Other than that, teaching and learning from home also could give a huge impact to some of the families who are struggling to own many devices in order to prepare for the lessons. Not all the parents are able to provide the facilities to their kids. Previously, to provide a device for each of the kids in a family is like giving them the speciality to explore the outside world. Some of the parents might reward their kids if they achieved good grades or showed good attitude. Nowadays, getting a device for the children becomes a must when all the platforms used to seek for the knowledge are all online. Sometimes, it could give pressure to both parents and children in order not to be left behind in the learning process. The huge impact is clearly seen from the teachers' side when they both are teachers and parents. It will be a challenging task for them to cope with a few things, for example teaching the pupils and also monitoring their own children who are having online classes at the same time. Teachers need to manage their children at home while delivering lessons to the pupils and both parties affected in this situation.

\section{Research Objectives and Research Questions}

The main objective of this systematic review is to present a systematic review from the past studies on how online teaching tools could enhance the interaction between ESL primary pupils among their friends and teachers. It also relates to the effectiveness of the 
usage of online learning tools. This could answer the research questions where it involves with;

1) How do online teaching and learning tools help primary ESL pupils to interact with their friends and teachers?

2) What are the benefits and challenges in using online teaching and learning tools in helping pupils to communicate with others during this pandemic?

Both teachers and pupils play an important role to ensure that this effort of learning online hits success. In order to find the effectiveness of using online tools in teaching and learning, teachers also need to figure out the ability of the pupils in engaging the interaction during online courses. The pupils need to consider the language used online due to the lack of faceto-face interactions in the online courses. The talkative pupils who normally take action during online class would eventually bring down the ability of certain pupils who are shy in real life due to lack of vocabulary or have poor speaking ability when they are in real life. The instructor could assign certain roles for the pupil's interaction to help them to improve their communication skill and to expose them to different styles of communication.

(Murali Krishnamurthi)

\section{Literature Review \\ Definition of Online Learning}

Living in the 21st century allows us to explore more about the current trend or style of learning in order to meet the global standard that can be applied to many aspects of teaching and learning programs. According to Pauline and Tian (2019), online learning gives flexibility and easy access to learning resources from virtually anywhere and at practically any hour of the day. We know that developing countries always want to prepare the best quality of teaching and learning criteria which can benefit the learners. The effectiveness of using online learning also would contribute to communicating effectively, handling technology, and distributing and evaluating material anywhere and at any time. They become the main criteria to produce an intensive online environment, which can help the learners to prepare their tools in a very short time (Chantal et al., 2017)

According to the majority of academics, it's "technologically enhanced access to learning activities." (Benson, 2002; Carliner, 2004; Conrad, 2002). They claimed that we can learn in a virtual way where long distance learning is promoted and at the same time promotes the opportunities to the learners and educators to explore the new era of teaching process. It will lead to access educational advantages where they can get a lot of information or learn in a very practical way. Other authors are not only focussed about online learning's accessibility, but also its connection, flexibility, and capacity to foster a variety of relationships in online teaching and learning process. (Ally, 2004; Hiltz \& Turoff, 2005; Oblinger \& Oblinger, 2005). Teaching and learning via online can be clarified as advanced tools of long distance learning medium where we can access anywhere and anytime. Teachers need to be creative in order to get students' attention and interest in the learning process. It is a challenging action taken by the teachers to find the correct or suitable technology, methods or tools to deliver the knowledge. In this crucial time, we are aware that everything is possible in order to succeed. The choices on which technology tools are suitable to be used can be overwhelming and daunting for the educators. 


\section{Online Teaching and Learning Tools}

The researcher is aware that many online too could help both teachers and learners to lead them in achieving their goals. There are various online tools available that can be used to conduct teaching and learning processes. Delivering methods can be changed time by time depending on the situation of the receiver. There are strengths and weaknesses of the tool that teachers might choose for their lesson. It comes in the video platform where teachers need to record all the teaching materials so that the pupils could learn anytime and anywhere. The interaction still occurred but the weaknesses of this platform are if pupils do not understand the content of the video, they might lose attention since there is nobody to monitor or guide them on the spot. Murday et al (2009) reported that some students can't focus properly during online learning due to some technical problems occurring and they keep fixing the problems which would result in delaying the process of learning. For example, the contents could be delivered by using Google Meet, Zoom meeting, Microsoft Teams, Telegram, WhatsApps and many more.

Other than that, teachers can divide the pupils into some groups and split them into the zoom breakout rooms where pupils are given chances to express their thoughts and share their opinion. The advantages from this activity is pupils are freely talk and discuss with their peers. They can interact with each other without the presence of the teacher. It would be a good way to practice their communication skills among their friends, especially for the pupils who are lacking self-confidence. The weaknesses of this style are some of the pupils who are very shy wouldn't take part since there are only a few members in the room so he or she would find that everybody must talk and it might give a little pressure to him/her.

During the lockdown, all the activities at school are being conducted online. Teachers need to equip themselves with the latest teaching style and learn many new things to attract pupils to join the lesson online by using platforms such as google meet, zoom, Microsoft team and other video platforms that allow teachers to keep in touch and even interact with the pupils. By having online classes through these platforms, pupils can virtually meet their friends and teachers to change opinions and also gain new knowledge. There are some weaknesses where some pupils might face difficulties while having the classes. All these platforms need a quality and strong internet connection to make sure that the class would not be interrupted. Other than that, spending lots of time in front of the devices also could give some negative impact to the pupils such as their attention span would easily distract. Teachers put many efforts to help and attract pupils especially in primary to. Many online teaching and learning tools were explored such as Padlets, Class Dojo, Blooket, Quizzi and many more to arouse their attention and boost their motivation to keep joining the online classes.

Online education would be a great approach to learn new things since it would allow teachers and students to use a variety of teaching and learning methods. If online education is as effective as traditional classroom learning, it can assist the community keep learning without having to move away from the traditional learning environment, says Chang (2020). Teachers and students can access digitally from many locations online by applying successful learning approaches. In the words of Horzum (2017): It can assist both teachers and students in remaining connected and boosting the educational process.

\section{Benefits of Online Teaching and Learning Tools}

Learning has never been easier without any materials and equipment so the usage of online learning tools become easy and reachable. Nowadays it involves more than what we can imagine as we are moving through development in technology. The acquisition of 
knowledge or skills through study has gone through so many changes since its start. In order to achieve this learning process much easier, there are tools being introduced. There are a variety of tools available that can be used nowadays to support the learning process which started from the classroom such as whiteboard and it does not stop even with online classrooms. Currently we are experiencing high demand for online classes rather than actual classrooms as people start to notice that online classes give much more flexibility and effectiveness. Online learning may happen anywhere and at any time as it is not required to go to the classroom physically. Furthermore, Information is accessible only within your fingertips because online tools are sufficient enough for the learning process with tons of resources online available without the need of moving around the library or places. The location of online learning, e-learning, Internet learning, distributed learning, networked learning, virtual learning, computer-assisted learning, web-based learning, distance learning, and so on are often used synonymously. As all of these terms suggested in online learning, to fulfil educational aims, Information and communication technologies (ICTs) are employed in conjunction with electronic media. Online-learning technologies involve Internet, one-way and two-way communications (Allen \& Seaman, 2017). These are the techniques of delivery that work as a bridge between the students and the educator (Angelino et al., 2007; Rovai, 2002). According to Pauline and Tian (2019), with various web technologies, the learners will prepare themselves with the opportunity to review and find the online learning stuff easily. Additionally, they have the option of studying in the most convenient and well-equipped location according to their own schedule and preferences.

As a result, students and instructors in online environments are often

geographically separated. The teacher offers teaching via some types of online delivery platforms, whereas students utilise the same virtual methods to access learning materials and engage with the teacher via online teaching and learning. (Anderson, 2008). Online learning is sometimes referred to as a flexible style of learning since it enables flexibility and quick access to learning resources at all times and from any location. Online learning, in contrast to typical face-to-face learning settings, offers greater flexibility and open access to large amounts of knowledge, which is very powerful and easily adapted in the current globalization. (Sitzmann et al., 2006). According to Driscoll et al (2012), this method permits students to transcend overcoming spatial and temporal limitations and have access to the most current and relevant learning resources at any time. Learners particularly have the freedom to learn at their own speed. Learners can communicate with peers, educators, and professionals in the subject via the online platforms. Learning materials are available for review and re-reading at any time. It is a huge impact to have a variety of online technologies.

The experts in the field of education have offered a variety of learning methods. By using many methods to enhance learning among the learners and educators, there are a lot of benefits and advantages that both sides can experience. The important thing that we could see is about the privileges that are provided in the fingertips. The learners could experience globally about the academic content that would contribute to their learning journey. One of the benefits is other than as a means of teaching pupils, its usage as professional enlargement, its cost-effectiveness in coping with growing postsecondary education costs, credit equivalence and the capacity to deliver services at the postsecondary level towards a worldclass education to anybody with a bandwidth acquaintance. (Bartley \& Golek, 2004; De la Varre, Keane, \& Irvin, 2011; Gratton-Lavoie \& Stanley, 2009; Koller \& Ng, 2014; Lorenzetti, 
2013). As an alternative for traditional classroom instruction, online learning has grown in popularity (Aboagye et al., 2020).

Therefore, teachers and parents also could monitor their children at home. Even though it is a challenging task for parents to monitor all their children at the same time, it also would benefit them regardless of time limit, they can easily access the learning material. In addition, it will help us in the hard times where it will be very flexible in terms of time and location because it is student centered learning where they are responsible towards their tasks. Teachers can set up their own teaching materials to be shared with the pupils in order to attract the attention of the learners. Teachers may tailor their procedures and processes to fit the demands of their students using e-learning approaches (Dhawan, 2020). A lot of online tools provided in the net that teachers can explore to lead to an effective and efficient learning environment. Teachers might experiment with various approaches to deliver the lesson. This can aid in the development of a collaborative and dynamic learning environment (Dhawan, 2020). In the middle of this upheaval, online learning is emerging as a victorious survivor. It may also lower the cost of the learning. The expense of attending college is rising faster than the rate of inflation, and student loan debt is rising as well (Nguyen, 2015). In further discussion, anyone with access to the Internet will be able to receive a world-class education through online learning (Nguyen, 2015)

\section{Challenges of Using Online Teaching and Learning Tools}

When comparing the developed world to developing nations, it was discovered that developing countries face problems such as poor internet access, insufficient understanding of how to utilise ICT, and a lack of content production. Aung \& Khaing (2015) During a pandemic, the online learning method has been used efficiently to guarantee that students continue with their education. However, there are certain difficulties with the online learning process. Boredom is a significant impediment to online learning. Students are often bored, especially if they are weak in a certain topic. Prior et al $(2016$, p. 95) stated that if learners do not optimise engagement with their peers and teachers, the online learning experience can rapidly become monotonous since contact between learners is limited. (Dağhan \& Akkoyunlu, 2016, p. 200). Online learning requires students to be accountable for themselves while learning at home alone, they may lose concentration. It is far more difficult for a student to acquire new knowledge or difficult ideas if they are distracted during the online learning process.

Additionally, online learning might be complicated by the presence of outside distractions. Games, social networking, and other free resources may distract students who are learning online. (Daly, 2019, p. 48). As a result, parents are crucial in ensuring that their children have the ability to focus fully. Another roadblock to online learning is a lack of technical knowledge. Students with little or no technological experience or those who need help using technology for educational purposes may find it difficult to succeed in online learning. (Anekwe, 2017). For students, relying on others for aid with technological devices and software may be ineffective and time-consuming, and it can also reduce the quality of the online learning process' outputs

\section{Method}

There are several procedures in conducting this review. PRISMA 2020, the Preferred Reporting Items for Systematic Review and Meta-Analysis (PRISMA) 2020 checklist, was 
used to perform this systematic literature review. 27 elements make up the systematic review checklist which is intended to increase openness.

By reviewing and selecting a few articles related to this study on using online learning tools to enhance interaction among the ESL primary school pupils with their peers and teachers, other researcher's thoughts were collected and had been justified in the tables. The whole procedure was divided into four distinct parts, including the identification phase, screening phase, eligibility phase, and finally, inclusion phase. Identifying articles relating to online teaching and learning tools is the first step in the process. By identifying the needs for the review, I figured out from many articles on how learning online tools could help pupils to enhance their ability in connecting with their peers and their teachers. Thus, teachers also could equip themselves with the latest and suitable teaching online tools to increase the interaction among the pupils then could help them to understand better. Next is about how the connection between their learning process could help them to excel in their studies. The last stage is when the result of the targeted issues raised up to help the pupils to achieve the highest ability in delivering the thoughts by their connectivity.

Phase 1: Identification Phase

For this comprehensive literature study, papers are being gathered from Google Scholar and ERIC. The range of the article publication was restricted from 2008 to 2020. Many journals are being collected and combined together in The Education Resources Information Center (ERIC) where most of the electronics materials are taken from this platform. However, Google Scholar is also one of the researchers' platforms to help the researcher in finding numerous educational articles worldwide. Table 1 shows the keywords that are being used to identify the related articles. The modification taken in this study is by adding the extra information about benefits and challenges of the selected articles.

\begin{tabular}{|l|l|}
\hline \multicolumn{1}{|c|}{ Databased } & Keywords \\
\hline Scholar & $\begin{array}{l}\text { Online learning interaction, distance learning, effectiveness of } \\
\text { online learning, E-learning, Online learning platforms, interaction } \\
\text { and effectiveness of online learning, factors of online learning }\end{array}$ \\
\hline ERIC & $\begin{array}{l}\text { Online learning attitudes, Online learning performances and } \\
\text { satisfaction, Online learning experience during Covid-19, Digital } \\
\text { skill and online learning, students' engagement in online learning }\end{array}$ \\
\hline
\end{tabular}

Table $1:$ Keywords used for the process of finding relevant literature

Phase 2: Screening Phase

After filtering articles from both databases, the similar articles are being removed accordingly. They were eventually picked depending on criteria that the researcher had 
specified. In other words, it's to make sure the papers picked are appropriate for the systematic review's goal.

Phase 3: Eligibility Phase

Starting from this phase, the selected articles are being filtered for their eligibility. The researcher classified them according to certain parameters. As a result of the third stage, it is imperative that the information and data obtained are suitable for the research project's goals. It also can make sure that the articles are retrieved from quality and reliability sources.

Phase 4: Exclusion Phase

This review was halted after the study was determined to be admissible. It was determined that the removed papers did not meet the requirements of current research questions. Same goes to the eligibility phase, the exclusion phase plays an important part in the systematic literature review to guarantee that the researcher is able to gather the quality data.

\begin{tabular}{|l|l|l|l|l|}
\hline $\begin{array}{l}\text { Article / } \\
\text { Study }\end{array}$ & $\begin{array}{l}\text { Topic of } \\
\text { research }\end{array}$ & $\begin{array}{l}\text { Research } \\
\text { design }\end{array}$ & $\begin{array}{l}\text { Discussi } \\
\text { on on } \\
\text { Benefits }\end{array}$ & $\begin{array}{l}\text { Discussion on } \\
\text { Challenges }\end{array}$ \\
\hline $\begin{array}{l}\text { Subhashni } \\
\text { (2008) }\end{array}$ & $\begin{array}{l}\text { A Review of } \\
\text { Benefits and of } \\
\text { Limitations of } \\
\text { Online Learning } \\
\text { in the Context of } \\
\text { the Student, the }\end{array}$ & Review & $\begin{array}{l}\text { Online education } \\
\text { offers more freedom } \\
\text { and flexibility than } \\
\text { traditional classroom } \\
\text { instruction. }\end{array}$ & $\begin{array}{l}\text { Beginner online } \\
\text { educators required } \\
\text { training. }\end{array}$ \\
\hline
\end{tabular}




\begin{tabular}{|c|c|c|c|c|}
\hline & $\begin{array}{l}\text { Instructor and } \\
\text { the Tenured } \\
\text { Faculty }\end{array}$ & & & \\
\hline $\begin{array}{l}\text { Tuan Nguyen } \\
\text { (2015) }\end{array}$ & $\begin{array}{l}\text { The } \\
\text { Effectiveness of } \\
\text { Online Learning: } \\
\text { Beyond No } \\
\text { Significant } \\
\text { Difference and } \\
\text { Future Horizons }\end{array}$ & $\begin{array}{l}\text { Research } \\
\text { article }\end{array}$ & $\begin{array}{l}\text { Students learning } \\
\text { outcomes for online } \\
\text { learners were as good } \\
\text { as or better than } \\
\text { traditional learner }\end{array}$ & $\begin{array}{l}\text { Online students did } \\
\text { much worse on } \\
\text { examinations than } \\
\text { traditional students, } \\
\text { despite having } \\
\text { higher GPAs score. }\end{array}$ \\
\hline $\begin{array}{l}\text { Emmanuel } \\
\text { Aboagye, } \\
\text { Joseph } \\
\text { Anthony } \\
\text { Yawson, Kofi } \\
\text { Nyantakyi } \\
\text { Appiah } \\
\text { (2020) }\end{array}$ & $\begin{array}{l}\text { COVID-19 and } \\
\text { E-Learning: The } \\
\text { Challenges of } \\
\text { Students in } \\
\text { Tertiary } \\
\text { Institutions }\end{array}$ & $\begin{array}{l}\text { Research } \\
\text { article }\end{array}$ & $\begin{array}{l}\text { Effective way of } \\
\text { transition from the } \\
\text { traditional classroom } \\
\text { to e-learning by } \\
\text { practicing blended } \\
\text { learning. }\end{array}$ & $\begin{array}{l}\text { In this pandemic } \\
\text { age, students were } \\
\text { not ready for online } \\
\text { learning and } \\
\text { preferred the } \\
\text { traditional method.. }\end{array}$ \\
\hline $\begin{array}{l}\text { Olasile } \\
\text { Babatunde } \\
\text { Adedoyin \& } \\
\text { Emrah } \\
\text { Soykan } \\
(2020)\end{array}$ & $\begin{array}{l}\text { Covid-19 } \\
\text { pandemic and } \\
\text { online learning: } \\
\text { the challenges } \\
\text { and } \\
\text { opportunities }\end{array}$ & $\begin{array}{l}\text { Research } \\
\text { article }\end{array}$ & $\begin{array}{l}\text { Educators can use } \\
\text { online learning to help } \\
\text { prepare kids during } \\
\text { this pandemic. }\end{array}$ & $\begin{array}{l}\text { Bad internet } \\
\text { connections and } \\
\text { online learning will } \\
\text { influence students } \\
\text { and educators. }\end{array}$ \\
\hline
\end{tabular}




\begin{tabular}{|l|l|l|l|l|}
\hline $\begin{array}{l}\text { Di Xu, Shanna } \\
\text { Smith Jaggars } \\
\text { (2012) }\end{array}$ & $\begin{array}{l}\text { The impact of } \\
\text { online learning } \\
\text { on students' } \\
\text { course } \\
\text { outcomes: } \\
\begin{array}{l}\text { Evidence from a } \\
\text { large } \\
\text { community and } \\
\text { technical college } \\
\text { system }\end{array}\end{array}$ & $\begin{array}{l}\text { Well prepared } \\
\text { article } \\
\text { learning had higher } \\
\text { grades and earned } \\
\text { more credits. }\end{array}$ & $\begin{array}{l}\text { An unprofessional } \\
\text { management } \\
\text { system will lead to } \\
\text { students' } \\
\text { incompetence in } \\
\text { online learning. }\end{array}$ \\
& & & \\
\end{tabular}

Table 2: Summary of past related-studies focussed on benefits and challenges of online learning

\begin{tabular}{|c|c|c|c|c|}
\hline $\begin{array}{l}\text { Article / } \\
\text { Study }\end{array}$ & Topic of research & $\begin{array}{l}\text { Research } \\
\text { design }\end{array}$ & Benefits & Challenges \\
\hline $\begin{array}{l}\text { Ibrahim } \\
\text { Mutambik } \\
(2018)\end{array}$ & $\begin{array}{l}\text { The Role of } \\
\text { E-learning in } \\
\text { Studying English as } \\
\text { a Foreign Language } \\
\text { in Saudi Arabia: } \\
\text { Students' and } \\
\text { Teachers' } \\
\text { Perspectives }\end{array}$ & Review & $\begin{array}{l}\text { Provides a forum for } \\
\text { students and teachers } \\
\text { to interact. }\end{array}$ & $\begin{array}{l}\text { It is difficult to use E- } \\
\text { learning without } \\
\text { prior knowledge and } \\
\text { supervision. }\end{array}$ \\
\hline $\begin{array}{l}\text { Daniah } \\
\text { Alabbasi, } \\
\text { ED.D (2018) }\end{array}$ & $\begin{array}{l}\text { Exploring Teachers } \\
\text { Perspectives } \\
\text { towards Using } \\
\text { Gamification } \\
\text { Techniques in } \\
\text { Online Learning }\end{array}$ & $\begin{array}{l}\text { Research } \\
\text { article }\end{array}$ & $\begin{array}{l}\text { Instant feedback, a } \\
\text { feature of online } \\
\text { courses, inspires } \\
\text { students to do better. }\end{array}$ & $\begin{array}{l}\text { Online courses } \\
\text { should be neither } \\
\text { too easy nor too } \\
\text { tough to discourage } \\
\text { students. } \\
\text { students from } \\
\text { learning. }\end{array}$ \\
\hline
\end{tabular}




\begin{tabular}{|c|c|c|c|c|}
\hline $\begin{array}{l}\text { Chrysi } \\
\text { Rapanta, } \\
\text { Luca Botturi, } \\
\text { Peter } \\
\text { Goodyear, } \\
\text { Lourdes } \\
\text { Guàrdia \& } \\
\text { Marguerite } \\
\text { Koole (2020) }\end{array}$ & $\begin{array}{l}\text { Online University } \\
\text { Teaching During } \\
\text { and After the } \\
\text { Covid-19 Crisis: } \\
\text { Refocusing Teacher } \\
\text { Presence and } \\
\text { Learning Activity }\end{array}$ & $\begin{array}{l}\text { Research } \\
\text { article }\end{array}$ & $\begin{array}{l}\text { The teacher can engage } \\
\text { students in a valuable } \\
\text { learning style that will } \\
\text { help them study better. }\end{array}$ & $\begin{array}{l}\text { The lesson's } \\
\text { instructional } \\
\text { objective must suit } \\
\text { the learners. }\end{array}$ \\
\hline $\begin{array}{l}\text { Kimmaree } \\
\text { Murday a , } \\
\text { Eiko Ushida } \\
\text { b \& N. Ann } \\
\text { Chenoweth } \\
\text { (2009) }\end{array}$ & $\begin{array}{l}\text { Learners' and } \\
\text { teachers' } \\
\text { perspectives on } \\
\text { language online }\end{array}$ & $\begin{array}{l}\text { Research } \\
\text { article }\end{array}$ & $\begin{array}{l}\text { Teachers were given } \\
\text { some freedom like } \\
\text { offline classes to design } \\
\text { their own teaching style } \\
\text { to deliver online. }\end{array}$ & $\begin{array}{l}\text { Teachers struggled } \\
\text { to keep track on } \\
\text { students' who are } \\
\text { not responsible } \\
\text { towards their online } \\
\text { tasks. }\end{array}$ \\
\hline $\begin{array}{l}\text { Elizabeth } \\
\text { Mastermana } \\
\text { and Marion } \\
\text { Manton } \\
\text { (2011) }\end{array}$ & $\begin{array}{l}\text { Teachers' } \\
\text { perspectives on } \\
\text { digital tools for } \\
\text { pedagogic planning } \\
\text { and design }\end{array}$ & Review & $\begin{array}{l}\text { Online learning allows } \\
\text { experienced educators } \\
\text { to adopt their } \\
\text { preferred approach to } \\
\text { design the activity to } \\
\text { help novice teachers. }\end{array}$ & $\begin{array}{l}\text { Lack of institution's } \\
\text { support would lead } \\
\text { to low quality of } \\
\text { learning design. }\end{array}$ \\
\hline
\end{tabular}

Table 3: Summary of past related- studies on teacher's perspective focussed on benefits and challenges of online learning 


\begin{tabular}{|c|c|c|c|c|}
\hline Article / Study & Topic of research & $\begin{array}{l}\text { Research } \\
\text { design }\end{array}$ & Benefits & Challenges \\
\hline $\begin{array}{l}\text { Muhammad } \\
\text { Adnan and } \\
\text { Kainat Anwar } \\
\text { (2020) }\end{array}$ & $\begin{array}{l}\text { Online learning } \\
\text { amid the COVID- } \\
19 \text { pandemic: } \\
\text { Students' } \\
\text { perspectives }\end{array}$ & $\begin{array}{l}\text { Research } \\
\text { article }\end{array}$ & $\begin{array}{l}\text { The administrations of } \\
\text { schools, colleges and } \\
\text { universities opted for } \\
\text { online lectures/classes } \\
\text { as an alternative way } \\
\text { to resume education }\end{array}$ & $\begin{array}{l}\text { They cannot profit } \\
\text { from online learning } \\
\text { because a big } \\
\text { amount of online } \\
\text { content is not } \\
\text { available } \\
\text { smartphones and } \\
\text { they lack sufficient } \\
\text { interaction with } \\
\text { teachers. }\end{array}$ \\
\hline $\begin{array}{l}\text { Abdelmalak, } \\
\text { Mariam } \\
\text { Mousa Matta } \\
\text { (2015) }\end{array}$ & $\begin{array}{l}\text { Web } 2.0 \\
\text { Technologies and } \\
\text { Building Online } \\
\text { Learning } \\
\text { Communities: } \\
\text { Students' } \\
\text { Perspective }\end{array}$ & $\begin{array}{l}\text { Research } \\
\text { article }\end{array}$ & $\begin{array}{l}\text { Encourage the growth } \\
\text { of learning } \\
\text { communities and } \\
\text { reduce student } \\
\text { isolation and distance } \\
\text { in online courses. }\end{array}$ & $\begin{array}{l}\text { Educators must } \\
\text { devise authentic } \\
\text { approaches to help } \\
\text { kids engage with } \\
\text { peers and form } \\
\text { connections. }\end{array}$ \\
\hline $\begin{array}{l}\text { Liyan Song, } \\
\text { Ernise S. } \\
\text { Singleton, } \\
\text { Janette R. Hill, } \\
\text { Myung Hwa } \\
\text { Koh (2004) }\end{array}$ & $\begin{array}{l}\text { Improving online } \\
\text { learning: Student } \\
\text { perceptions of } \\
\text { useful and } \\
\text { challenging } \\
\text { characteristics }\end{array}$ & $\begin{array}{l}\text { Research } \\
\text { article }\end{array}$ & $\begin{array}{l}\text { Online learning allows } \\
\text { more student's reflect } \\
\text { and generate their } \\
\text { ideas. }\end{array}$ & $\begin{array}{l}\text { Delay of immediate } \\
\text { response from the } \\
\text { educators makes } \\
\text { students } \\
\text { demotivated feel } \\
\text { frustrated. }\end{array}$ \\
\hline
\end{tabular}




\begin{tabular}{|c|c|c|c|c|}
\hline $\begin{array}{l}\text { Laura Salmi } \\
\text { (2013) }\end{array}$ & $\begin{array}{l}\text { Student } \\
\text { Experiences On } \\
\text { Interaction In An } \\
\text { Online Learning } \\
\text { Environment As } \\
\text { Part Of A Blended } \\
\text { Learning } \\
\text { Implementation: } \\
\text { What Is Essential? }\end{array}$ & $\begin{array}{l}\text { Research } \\
\text { article }\end{array}$ & $\begin{array}{l}\text { An online } \\
\text { environment can be a } \\
\text { good platform to } \\
\text { foster investigative } \\
\text { learning. }\end{array}$ & $\begin{array}{l}\text { Finding time for all } \\
\text { team members to } \\
\text { work together and } \\
\text { controlling different } \\
\text { ideas through online } \\
\text { learning is difficult. }\end{array}$ \\
\hline $\begin{array}{l}\text { Montgomery } \\
\text { Van Wart, } \\
\text { Anna Ni, } \\
\text { Pamela } \\
\text { Medina, Jesus } \\
\text { Canelon, } \\
\text { Melika } \\
\text { Kordrostami, } \\
\text { Jing Zhang and } \\
\text { Yu Liu (2020) }\end{array}$ & $\begin{array}{l}\text { Integrating } \\
\text { students' } \\
\text { perspectives } \\
\text { about online } \\
\text { learning: } r \\
\text { hierarchy } \\
\text { factors }\end{array}$ & $\begin{array}{l}\text { Research } \\
\text { article }\end{array}$ & $\begin{array}{l}\text { Online learning } \\
\text { become a } \\
\text { convenience and } \\
\text { flexibility, and has } \\
\text { personal notions of } \\
\text { suitability about } \\
\text { learning }\end{array}$ & $\begin{array}{l}\text { Unprepared teaching } \\
\text { leads to demotivated } \\
\text { students. }\end{array}$ \\
\hline $\begin{array}{l}\text { Kimmaree } \\
\text { Murday a, } \\
\text { Eiko Ushida b } \\
\text { \& N. Ann } \\
\text { Chenoweth } \\
\text { (2009) }\end{array}$ & $\begin{array}{l}\text { Learners' and } \\
\text { teachers' } \\
\text { perspectives on } \\
\text { language online }\end{array}$ & $\begin{array}{l}\text { Research } \\
\text { article }\end{array}$ & $\begin{array}{l}\text { Online and offline } \\
\text { study kept some } \\
\text { students busy and } \\
\text { helped them manage } \\
\text { their time well. }\end{array}$ & $\begin{array}{l}\text { Less time on } \\
\text { technological issues } \\
\text { during online classes, } \\
\text { students discovered. }\end{array}$ \\
\hline
\end{tabular}

Table 4: Summary of past related- studies on students' perspective focussed on benefits and challenges of online learning

\section{Result}

From all the procedures mentioned in conducting this systematic review, 30 articles have been filtered and only 15 articles were chosen to be reviewed from past related studies on using online teaching as a platform and tool to increase the interaction among pupils and teachers from year 2008 to 2020 were selected. The empirical results to support this study on the use of online learning to improve connectivity among pupils and teachers to help primary 
pupils in their independent learning through the Internet are summarised in Table 2, Table 3 and Table 4 as follows:

Results shown in the tables above indicate that the majority of the studies identify the following components as helpful in online teaching and learning tools. As shown in Table 2, there are some benefits and challenges that people face while experiencing online teaching and learning instruments. It depicts a favourable attitude toward the learning environment, which is commonly used by students and teachers. It also aided the growth of the educational system during this time period.

Table 3 shows the perspective among teachers in reflecting on the benefits and challenges from the online teaching method. The past related studies agreed that online teaching could help teachers to monitor their students and interact effectively. At the same time, teachers also need to equip themselves with the latest technology knowledge in order to deliver the lesson smoothly. The effective online lesson depends on teachers' involvement in online teaching strategy. It also could help the progress of students' achievement especially during the pandemic time where students are on their own. Students might need support from the teachers since most of them, especially primary school pupils, are completely learning independently at home compared to the conventional learning method in a classroom environment.

However, from Table 4, the result shown about students' perspective on online learning practice could benefit them and at the same time they would experience some challenges. From the articles chosen, it can be concluded that all the education institutions were shut down for physical learning. So, online learning would be the best option for students to keep seeking knowledge without hiatus and can pursue the learning according to the syllabus planned. Most of the education institutions took proactive initiative to help the students to complete their studies. Despite the positivity from online learning, there are also some threats that students need to face. Some of them might not have enough sources to get the maximum opportunity to access online learning.

\section{Discussion}

This study emphasized on how online teaching and learning tools could help both teachers and students to meet their needs. The most preferable tool that encourages the interaction among teachers and students would be anything that is easy to access by both parties such as Google Classroom. It was found that online teaching and learning tools could help them to interact with each other actively. From the platform, teachers and students would engage frequently especially during this tough period. It would benefit students in many aspects since they need guidance from the teachers to excel in their journey of learning. Si Zhang et al (2017) stated that the community in online learning could support the teachers especially for the primary level to gain more skills then can contribute to the improvement of pupils' achievement.

From teachers' perspective, the researchers stated that teachers play an important role to help the students succeed. During this challenging period, teachers were change agents and nation builders. Teachers are the primary agents in assisting and maintaining pupils' varied skill development. Teachers also need to be well versed in preparing suitable pedagogy with the help of technology to suit students' needs. Nevertheless, there are also some challenges in conducting online teaching in order to provide the greatest experience for the students. Teachers need to know the background of their students so that teachers will acknowledge the difficulties facing them during this remote learning. Rasmitadila, Rusi Rusmiati Aliyyah, 
Reza Rachmadtullah, Achmad Samsudin, Ernawulan Syaodih, Muhammad Nurtanto and Anna Riana Suryanti Tambunan (2020) mentioned that a teacher must respond to all challenges that arise in online learning responsively to meet the specific goals in conducting online learning.

The perspective of the students also needs to be taken into consideration in contributing to the successful online learning that could benefit all the parties involved. It would help the students to broaden their opportunities in their studies. The past studies claimed about the importance of the connectivity among students with their teachers and also between their peers. Some students found it very hard to set up the online meeting group to do online tasks since everybody has their own responsibility at home and some might face technical errors. Salmi (2013) noted that each student has a unique schedule, making it impossible to create a schedule for each member.

\section{Findings}

The findings from all of the studies demonstrated that online learning had advantages. Both students and teachers may profit from this. Online technologies for teaching and learning have been found to be beneficial to both students and teachers in the current era. By using the online platform, it could help students and teachers to increase their interaction even though they are not having a physical interaction. Teaching and learning are still going on to make sure that they are no students left behind in gaining the knowledge. The online platform used such like Zoom call, Google Meet, Google Classroom and many more could help both teachers and students to stay connected to each other.

The finding of the study also emphasized on the importance and benefits of online teaching and learning tools during this pandemic. It highlighted the flexibility of online learning tools towards students. They can complete their tasks based on their own time, pace and ability. At the same time, teachers also can monitor the progress of the students' work easily. Teachers even can grade them according to the students' performances. In addition, it also can attract students' attention in participating in online learning because they can interact with their peers while using their smartphone. The students would feel more comfortable to use the devices since they are staying at home while attending the online learning courses. Besides, there are also challenges faced by both teachers and students while conducting the online teaching and learning. Even though online teaching and learning provide a lot of advantages, it also has some flaws that teachers and students need to be aware of. For example, it would not always fit the specialty of students and teachers in the field of technology. Some of them might experience it for the first time and would not be able to master the features of the online teaching and learning tools. Not all the users have the privilege of the strong internet connection at their places.

\section{Conclusion}

As a whole, this comprehensive review of the literature offers helpful insights for educators and students involved in online teaching and learning. Reviewing changes in online teaching and learning over the last few years and determining how it can assist users in the future was the goal of this study. Study after study has shown that today's education system benefits from online teaching and learning platforms. In addition, it's a great way to help students improve their communication skills and their capacity to engage and interact online with others. It also teaches children how to be digitally literate, a skill that will be useful in their future employment. 
Aside from that, online tools for teaching and learning would assist students in becoming proficient in using an online strategy. Students must understand the need of becoming self-sufficient consumers in our modern society, which is characterised by a high demand for radical technological changes.

\section{Limitations and Recommendations for Futur Research and Practice}

The findings of this systematic study revealed that students of all levels may benefit from online learning. By implementing the idea to expose the usage of online learning as a tool for education purposes, it also would increase the interaction among teachers and pupils. In addition, it would help the learning become better and up to date. Using data from prior studies, this systematic review examines how online learning might help both students and instructors. The first limitation is the internet connection provided in certain places that might give impact to the users. It is the most important aspect for this study where it relies on the aspect of connectivity to reach the usage of online learning. The poor connectivity might lead to the frustration of the users to continue using this method. Mohamed Aziz Dridi, Dhinesh Radhakrishnan, Barbara Moser-Mercer and Jennifer DeBoer found that teachers felt powerless to help their pupils participate in class discussions during online learning due to periodic connection problems.

It showed that the respondents agreed that the usage of online learning could help them to get the information anytime and anywhere. The main focus showed that teachers could collaborate well through online learning without any pupils left behind. Furthermore, the results from other researchers say that it is recommended for teachers to prepare themselves with the current trend in the education field. The future research that can be conducted is to explore more about the application that is very useful to help the pupils to excel in their studies. Nowadays, since the style of teaching and learning has become the main topic among the public, it gives early understanding that this style of learning should be exposed and practiced around the world. Early exposure towards the specialty and the function of online learning must be a priority in the online teaching and learning setting.

\section{References}

Abdelmalak, M. M. M. (2015). Web 2.0 Technologies and Building Online Learning Adnan, M., \& Anwar, K. (2020). Online Learning amid the COVID-19 Pandemic: Students' Agustina, P. Z. R., \& Cheng, T. H. (2020). How Students' Perspectives about Online Learning Amid the COVID-19 Pandemic?. Studies in Learning and Teaching, 1(3), 133-139.

Alabbasi, D. (2018). Exploring Teachers' Perspectives towards Using Gamification Techniques in Online Learning. Turkish Online Journal of Educational Technology-TOJET, 17(2), 3445.

Aliyyah, R. R., Rachmadtullah, R., Samsudin, A., Syaodih, E., Nurtanto, M., \& Tambunan, A. R. S. (2020). The perceptions of primary school teachers of online learning during the COVID-19 pandemic period: A case study in Indonesia. Journal of Ethnic and Cultural Studies, 7(2), 90-109.

Arabia: Students' and Teachers' Perspectives. English Language Teaching, 11(5), 74-8 Assessment \& Evaluation in Higher Education, 30(6), 581-592.

Chalkiadaki, A. (2018). A systematic literature review of 21st century skills and competencies in primary education. International Journal of Instruction, 11(3), 1-16.

Communities: Students' Perspectives. Online Learning, 19(2), n2. 
Dridi, M. A., Radhakrishnan, D., Moser-Mercer, B., \& DeBoer, J. (2020). Challenges of Blended Learning in Refugee Camps: When Internet Connectivity Fails, Human Connection Succeeds. The International Review of Research in Open and Distributed Learning, 21(3), 250-263.

Gamliel, E., \& Davidovitz, L. (2005). Online versus traditional teaching evaluation: Mode can matter.

Kazmer, M. M., \& Haythornthwaite, C. (2005). Multiple perspectives on online learning. ACM SIGGroup Bulletin, 25(1), 7-11.

Kılıç, M. E. (2021). What are the expectations of primary school teachers from instructional leaders during the distance education period. Athens Journal of Education.

Muljana, P. S., \& Luo, T. (2019). Factors contributing to student retention in online learning and recommended strategies for improvement: A systematic literature review. Journal of Information Technology Education: Research, 18.

Murday, K., Ushida, E., \& Chenoweth, A. N. (2008). Learners' and teachers' perspectives on language online. Computer assisted language learning, 21(2), 125-142.

Murphy, E., \& Rodríguez-Manzanares, M. A. (2009). Teachers' perspectives on motivation in high-school distance education. International Journal of E-Learning \& Distance

Mutambik, I. (2018). The Role of e-Learning in Studying English as a Foreign Language in Saudi Perspectives. Online Submission, 2(1), 45-51.

Soni, V. D. (2020). Global Impact of E-learning during COVID 19. Available at SSRN 3630073.

Sun, L. P., Siklander, P., \& Ruokamo, H. (2018, June). How to trigger students' interest in digital learning environments: A systematic literature review. In Seminar. net (Vol. 14, No. 1, pp.

Tularam, G. A. (2018). Traditional vs Non-traditional Teaching and Learning Strategies-the case of E-Learning!

Van Wart, M., Ni, A., Medina, P., Canelon, J., Kordrostami, M., Zhang, J., \& Liu, Y. (2020). Integrating students' perspectives about online learning: a hierarchy of factors. International Journal of Educational Technology in Higher Education, 17(1), 1-22.

Zhang, S., Liu, Q., Chen, W., Wang, Q., \& Huang, Z. (2017). Interactive networks and social knowledge construction behavioral patterns in primary school teachers' online collaborative learning activities. Computers \& Education, 104, 1-17. 